\title{
TRANSPARANSI APBD SEBAGAI SARANA AKUNTABILITAS PUBLIK \\ DAN GOOD GOVERNANCE
}

Oleh

Fatmasari Sukesti,SE,M.Si

Drs. Alfasadun,MM,Akt

\begin{abstract}
Abstrak
Global crisis happened in Indonesia we have been aware of the importance of decentralization and regional autonomy in the real sense. The policy is based thinking to ensure efficiency, effectiveness, transparency, accountability and democratic values of the people in the exercise of government. The implications of such arrangements include the preparation of Revenue and Expenditure (APBD) and performance-based accountability and comprehensive financial reports as a form of accountability to check the Supreme Audit Agency (BPK). Arrangements and financial accountability is very urgent as a tool to bring transparency in public accountability for achieving good governance

Keywords: autonomy, accountability, budget, transparency
\end{abstract}

\section{PENDAHULUAN}

\section{Latar Belakang}

Seluruh Propinsi dan Kabupaten/ Kota di Indonesia dijadikan sebagai daerah otonomi oleh Pemerintah Pusat, dalam arti Pemerintah Pusat memberikan kewenangan untuk mengatur dan mengurus kepentingan masyarakatnya sendiri sesuai dengan aspirasi yang berkembang di masyarakat masing masing Propinsi dan Kabupaten/Kota yang bersangkutan. Otonomi daerah berimplikasi pada pendelegasian kewenangan disertai dengan penyerahan dan pengalihan pembiayaan, sarana dan prasarana, serta sumber daya manusia dalam rangka Desentralisasi Fiskal

Otonomi daerah diatur dalam regulasi Undang-Undang Nomor 17 Tahun 2003 tentang Keuangan Negara yang mengatur hubungan keuangan antara Pusat- Daerah dan pertanggungjawaban pengelolaan keuangan oleh pemerintah daerah. Undang-undang ini mengatur tentang pengertian dan ruang lingkup keuangan Negara, asas-asas umum pengelolaan keuangan Negara, kedudukan Presiden sebagai pemegang kekuasaan pengelolaan keuangan 
Negara, pendelegasian kekuasaan Presiden, penyusunan APBN/APBD, hubungan antara pemerintah pusat dan bank sentral, pemerintah daerah dan pemerintah Pusat, mengatur hubungan antara perusahaan daerah dan swasta dan juga bentuk serta batas waktu penyampaian laporan pertanggungjawaban APBN dan APBD.

Anggaran pemerintah daerah yang dituangkan dalam APBD adalah alat akuntabilitas, manajemen dan kebijakan ekonomi daerah. Sebagai upaya mewujudkan pemerintahan yang baik dan bersih (Good Governance), transparansi APBD merupakan salah satu aspek penting dalam menjalankan program pemerintah daerah, dan secara umum dalam usaha meningkatkan kesejahteraan masyarakat daerah tersebut. Pemerintah daerah diharapkan untuk dapat meningkatkan efisiensi pemanfaatan anggaran dalam menjalankan program-programnya, agar dapat memenuhi kebutuhan masyarakat secara efektif, dalam hal ini akuntabilitas menjadi isu yang sangat penting dalam menjaga efisiensi dan efektivitas anggaran pemerintah.

Asian Development Bank (ADB) dalam sebuah seminar di Fukuoka Jepang pada tanggal 10 Mei 1997 memberikan kesimpulan bahwa pemerintahan yang baik dan bersih (good and clean government) merupakan faktor penting dalam sebuah proses pembangunan (ADB, 1997). Empat elemen penting pemerintahan yang baik dan bersih yaitu (1) accountability, (2) transparancy, (3) predictability, dan (4) participation. Sehingga good governance pada pemerintah daerah berarti mengelola sumber daya sosial dan ekonomi untuk kepentingan pembangunan masyarakat dengan mempertimbangkan aspek politik, aspek ekonomi dan aspek administrative yang berimplikasi pada pemerataan, penurunan kemiskinan serta peningkatan kualitas hidup masyarakat di daerah. Atas dasar latar belakang di atas penulis memilih judul "Transparansi APBD sebagai sarana

\section{Akuntabilitas Publik dan Good Governance”}

\section{Batasan Masalah}

Akuntabilitas sektor publik dalam hal ini pemerintah daerah dapat dilakukan melalui akuntansi sektor publik dan transparansi APBD. Artikel ini dibatasi pada transparansi APBD yang bagaimana seharusnya dijalankan oleh pemerintah daerah sebagai upaya awal terhadap transparansi keuangan sektor publik / pemerintah daerah kepada masyarakat. 


\section{Tujuan dan Manfaat}

1. Memperoleh gambaran mengenai persoalan-persoalan yang timbul yang secara langsung maupun tidak langsung mempengaruhi akuntabilitas pengelolaan keuangan daerah dan langkah-langkah strategis yang wajib dilaksanakan oleh pemerintah daerah untuk memperoleh kualitas terbaik opini Wajar Tanpa Pengecualian berdasarkan pengalaman pengelola akuntansi pemerintah daerah.

2. Memperoleh gambaran pentingnya reformasi birokrasi dalam meningkatkan transparansi dan akuntabilitas Pemerintah Daerah dan program nasional percepatan reformasi birokrasi daerah di seluruh provinsi yang oleh Kementerian PAN dan RB

3. Memperoleh pemahaman secara mendalam terkait proses penentuan opini pemeriksaan LKPD oleh BPK RI sesuai UU No. 15 Tahun 2004 tentang Pemeriksaan Pengelolaan dan tanggung Jawab Keuangan Negara dan permasalahan ketidak beresan, ketidakteraturan dan ketidakbenaran dalam pengelolaan dan pertanggungjawaban keuangan daerah termasuk banyaknya aset negara yang dilaporkan secara tidak wajar dalam laporan keungan yang mempengaruhi pemberian opini oleh BPK RI yang harus segera ditindaklanjuti oleh seluruh jajaran aparat pemerintah daerah.

\section{STUDI LITERATUR}

Reformasi di Indonesia membawa perubahan terhadap sistem politik, sosial, kemasyarakatan serta ekonomi sehingga menimbulkan tuntutan terhadap pengelolaan pemerintahan yang baik (good governance). Salah satu agenda reformasi adalah desentralisasi keuangan dan otonomi daerah yang dituangkan dalam Undang Undang Nomor 32 Tahun 2004 tentang Pemerintahan Daerah dan Undang Undang Nomor 33 tentang Perimbangan Keuangan Antara Pemerintah Pusat dan Pemerintah daerah.

Penerapan prinsip good governance semakin didukung dengan diterapkan UU No.14 tahun 2008 tentang Keterbukaan Informasi Publik. Dampak dari Undang Undang ini sangat besar dalam transparansi kebijakan publik, sehingga seluruh elemen masyarakat memiliki hak sama untuk memperoleh informasi publik dari semua lembaga pemerintahan, termasuk anggaran 
pemerintah daerah yang dituangkan dalam APBD. Peran anggota DPRD juga diperlukan sebagai fungsi pengawasan anggaran.

Penelitian yang dilakukan oleh Andriani (2002, Indradi, 2001; Syamsiar, 2001; Sutarnoto, 2002), menyimpulkan bahwa pengetahuan anggaran dan partisipasi masyarakat berpengaruh secara signifikan terhadap pengawasan keuangan daerah yang dilakukan oleh Dewan Perwakilan Rakyat Daerah. Sehingga tranparansi APBD sebagai bagian akuntabilitas sektor publik sangat diperlukan dalam rangka mewujudkan pemerintahan yang baik dan bersih.

Sebagai upaya mewujudkan pemerintahan yang baik dan bersih tersebut, akuntansi pemerintahan merupakan salah satu aspek penting dalam menjalankan program perekonomian pemerintah, dan secara umum dalam usaha meningkatkan kesejahteraan masyarakat. Pemerintah diharapkan dapat melakukan efisiensi anggaran dalam menjalankan program-programnya, agar dapat memenuhi kebutuhan masyarakat secara efektif.

Permasalahan dalam pengelolaan dan pertanggungjawaban keuangan daerah adalah masih banyaknya ditemukan ketidakberesan, ketidakteraturan dan ketidakbenaran, dan bahkan penyimpangan dalam pengelolaan serta pertanggungjawaban keuangan daerah dan laporan realisasi anggaran termasuk banyaknya aset negara yang dikelola secara tidak layak dan dilaporkan secara tidak wajar dalam laporan keuangan yang berimplikasi pada opini Badan Pemeriksa Keuangan (BPK) atas laporan keuangan pemerintah daerah Berdasarkan UU No. 15 Tahun 2004, tentang Pemeriksaan Pengelolaan dan tanggung Jawab Keuangan Negara, BPK memberikan opini atas LKPD berupa opini Wajar Tanpa Pengecualian (Unqualified Opinion), Wajar Dengan Pengecualian (Qualified Opinion), Tidak Wajar (Adverse Opinion) dan Tidak Memberikan Pendapat (Disclaimer Opinion).

Masalah yang menonjol dan mempengaruhi kewajaran penyajian laporan keuangan, dimulai penganggaran yang tidak sesuai dengan ketentuan peraturan perundang-undangan, pelaksanaan realisasi belanja dan pendapatan yang tidak akuntabel dan pertanggungjawaban yang tidak layak, yang pada akhirnya berimbas pada laporan keuangan yang tidak disajikan secara wajar sesuai dengan standar akuntansi pemerintah. Selain Standar Akuntansi Pemerintah, penyusunan laporan keuangan juga harus sesuai dengan ketentuan peraturan perundangundangan lainnya, seperti Peraturan Presiden dalam hal kegiatan pengadaan (Perpres 54 Tahun 2010 direvisi Perpres 70 Tahun 2012), Peraturan Menteri Dalam Negeri terkait pengelolaan aset atau barang milik daeran (permendagri 17) dan ketentuan-ketentuan terkait dengan pengelolaan 
keuangan daerah lainnya. Sehingga hasil audit BPK RI atas LKPD se-Indonesia Tahun 2010 untuk kualitas terbaik kewajaran Laporan Keuangan Pemerintah Daerah berupa opini Wajar Tanpa Pengecualian hanya diberikan terhadap 34 daru 524 LKPD (6\%), perolehan opini WTP tersebut sudah meningkat dari tahun sebelumnya yang hanya diperoleh 15 LKPD dari $524 \operatorname{LKPD}(3 \%)$.

Gerakan mengajak masyarakat untuk bersama-sama mengawal APBD mulai memperoleh gaungnya di daerah. Ini terjadi di Ponorogo, Jatim. Sedikitnya 150-an mahasiswa kota tersebut, dalam berita Rabu (31/10), berunjuk rasa dengan turun ke jalan guna menuntut adanya transparansi penggunaan APBD Ponorogo. Mahasiswa yang tergabung dalam aliansi Mahasiswa Anti Korupsi Ponorogo menggunakan sepeda motor dan membawa spanduk serta poster bertuliskan tuntutan mereka. Para mahasiswa menilai pemkab dan muspida tidak transparan dalam penggunaan APBD. Hal ini membuktikan banyaknya program yang tidak sampai ke masyarakat.

\section{PERMASALAHAN}

Oleh karena penyelenggaraan otonomi daerah secara luas, nyata dan bertanggungjawab merupakan kebutuhan masyarakat daerah, maka otonomi daerah harus dipahami sebagai hak atau kewenangan masyarakat daerah untuk mengelola dan mengatur urusannya sendiri. Aspek atau peran pemerintah daerah tidak lagi merupakan alat kepentingan pemerintah pusat belaka, melainkan alat untuk memperjuangkan aspirasi dan kepentingan daerah. Untuk melaksanakan hal di atas, pemerintah kemudian mengeluarkan Keputusan Menteri Dalam Negeri Nomor 29 Tahun 2002 tentang Pedoman Pengurusan, Pertanggungjawaban dan Pengawasan Keuangan Daerah serta Tata Cara Penyusunan Anggaran Pendapatan dan Belanja Daerah, Pelaksanaan Tata Usaha Keuangan Daerah dan Penyusunan Perhitungan Anggaran Pendapatan dan Belanja Daerah, yang ditetapkan pada tanggal 10 Juni 2002, sebagai pelaksanaan pasal 14 ayat (4) Peraturan Pemerintah Nomor 105 Tahun 2000 tentang Pengelolaan dan Pertanggung Jawaban Keuangan Daerah.

Ada beberapa hal yang berubah dalam penyusunan APBD berdasarkan pola baru dibandingkan dengan penyusunan APBD berdasarkan pola lama. Penyusunan APBD berdasarkan Kepmendagri Nomor 29 tahun 2002 dimulai dengan proses penyusunan Arah dan 
Kebijakan Umum (AKU) oleh Pemerintah Daerah bersama DPRD, dengan berpedoman pada Rencana Strategis (Renstra) Daerah dan atau dokumen perencanaan daerah lainnya yang ditetapkan daerah, serta pokok-pokok kebijakan nasional dibidang keuangan daerah oleh Mendagri.

Setelah Arah dan Kebijakan Umum (AKU) tersusun, maka tahap selanjutnya Kepala Daerah melalui Tim Anggaran Eksekutif menyusun Strategi dan Prioritas RAPBD yang nantinya sebagai pedoman bagi perangkat daerah dalam menyusun usulan Program, Kegiatan dan Anggaran. Setelah itu baru disusun Rencana Anggaran Satuan Kerja (RASK) dan Dokumen Anggaran Satuan Kerja (DASK) oleh masing-masing unit kerja dan setelah dibahas oleh Pemerintah Daerah bersama DPRD, akan disahkan menjadi Rancangan Anggaran Pendapatan dan Belanja Daerah (RAPBD). Penyusunan RAPBD berdasarkan Kepmendagri Nomor 29 tahun 2002 ditekankan pada penyusunan dan pengelolaan anggaran daerah yang berorientasi pada pencapaian hasil atau kinerja. Kinerja mencerminkan efisiensi dan efektivitas pelayanan publik, yang berarti berorientasi pada kepentingan publik.

Yang menjadi permasalahan publik tentang transparansi yang diharapkan masyarakat adalah bahwa APBD yang dipublikasikan pada masyarakat belum memenuhi harapan transparansi yaitu bahwa APBD masih disajikan secara global termasuk sumber sumber pendapatan dan pengeluarannya, sehingga dalam pengawasan penerimaan dan pengeluaran APBD masih sangat memungkinkan disalahgunakan, karena juga tidak disebutkan jenis, tarip misalnya dalam konteks sumber pendapatan dalam propinsi yang berasal dari pajak kendaraan bermotor. Atau dana alokasi dari tingkat pemerintahan yang lebih tinggi yang diberikan/ dikucurkan kepada pemerintahan yang berada dibawahnya harus diberitahukan ketika APBN/APBD ditetapkan.

\section{PEMBAHASAN}

Teori keagenan ( Agency Teory) dapat digunakan untuk menghubungkan tanggung jawaban sektor publik dimana masyarakat berperan sebagai pemberi amanah sekaligus sebagai pemilik (owner) dan pelanggan (customer). Pemerintah Daerah dengan peran dan fungsinya sebagai pemberi pelayanan kepada masyarakat (civil service) atau dengan kata lain sebagai manajemen. Dalam organisasi sektor publik, pemerintah daerah/Pemda berperan sebagai agen 
dan publik/masyarakat berperan sebagai prinsipal yang memberikan otoritas kepada DPRD untuk mengawasi kinerja pemerintah daerah.

Akuntabilitas menjadi suatu konsekuensi logis adanya hubungan antara agen dan prinsipal. Dari sisi teori keagenan, dapat dinyatakan bahwa pengawasan yang dilakukan oleh legislatif terhadap anggaran yang dilaksanakan oleh eksekutif merupakan suatu mekanisme untuk mengurangi adanya asimetri informasi atau mengurangi ketidakpastian. Pengawasan diperlukan untuk mengukur dan memprediksi tujuan serta peluang untuk melakukan intervensi terhadap aktivitas yang sesuai dengan yang diharapkan.

Transparansi adalah salah satu prinsip good governance. Dalam Mardiasmo (2003) menyebutkan kerangka konseptual dalam membangun transparansi dan akuntabilitas organisasi sektor publik dibutuhkan empat komponen yang terdiri dari : 1) Adanya sistem pelaporan keuangan; 2) Adanya sistem pengukuran kinerja; 3) Dilakukannya auditing sektor publik; dan 4) Berfungsinya saluran akuntabilitas publik (channel of accountability). Anggaran yang disusun oleh pihak eksekutif dikatakan transparansi jika memenuhi beberapa kriteria berikut : 1)Terdapat pengumuman kebijakan anggaran, 2) Tersedia dokumen anggaran dan mudah diakses, 3) Tersedia laporan pertanggungjawaban yang tepat waktu, 4) Terakomodasinya suara/usulan rakyat, 5) Terdapat sistem pemberian informasi kepada publik. Asumsinya semakin transparan kebijakan publik, yang dalam hal ini adalah APBN/APBD maka pengawasan yang dilakukan oleh Dewan dan masyarakat akan semakin meningkat karena masyarakat juga terlibat dalam mengawasi kebijakan publik.

Partisipasi masyarakat yang diberikan oleh pemerintah pusat melalui otonomi daerah sebagai bagian dari semangat good governance dapat dilakukan dalam penyusunan APBD maupun dalam pengawan pelaksanaannya. Karena anggaran pendapatan dan belanja daerah (APBD) adalah arah kebijakan pemerintah daerah yang diwujudkan dalam langkah-langkah nyata pembangunan daerah.

Partisipasi rakyat dalam penganggaran (APBD) dilakukan melalui public hearing. Masyarakat secara bersama-sama dalam bentuk institusi publikseperti LSM, Ormas, Pers dapat mengoptimalkan peran mereka dalam mekanisme APBD termasuk dalam pengawasan APBD. Masyarakat semakin cerdas, peka dan peduli terhadap permasalah sosial maupun politik yang berkembang di masyarakat. Peran masyarakat sudah terlihat pada tahap penyusunan APBD 
dimana masyarakat memberikan masukan berupa aspirasi dan kebutuhannya yang dapat dikoordinir oleh instansi Musyawarah Pembangunan Desa dan Kelurahan. Partisipasi masyarakat dalam penyelenggaraan negara turut didukung oleh Peraturan Pemerintah Republik IndonesiaNomor 68 Tahun 1999 tentang Tata Cara pelaksanaan, peran serta masyarakat dalam penyelenggaraan Negara. Produk hukum daerah berupa Perda tentang PenyampaianPartisipasi oleh Rakyat/Masyarakat di Daerah perlu dibentuk agar proses legislasi dan pengawasan di masing-masing daerah berjalan optimal sehingga tata pemerintahan yang baik dapat terwujud.

Transparansi APBD adalah bentuk akuntabilitas pemerintah daerah dalam kerangka menjaga anggaran agar sesuai dengan tujuan penggunaannya. Bentuk bentuk transparansi APBD dapat dilakukan antara lain:

1) Dalam hal sumber pendapatan APBD, aparat perpajakan harus melakukan transparansi dengan menyebutkan sumber pendapatan, jenis, taripnya secara rinci. Transparansi pendapatan dikatakan transparan jika memuat detail informasi tentang pendapatan. Misalnya dalam konteks sumber pendapatan dalam propinsi yang berasal dari pajak kendaraan bermotor, transparansi Pajak Kendaraan Bermotor (PKB) haruslah menyebutkan tentang jumlah kendaraan bermotor yang dirinci pada jenisnya (sedan, truk, dan sebagainya), tarif per kendaraan bermotor.

2) Kemudian dari sisi penggunaan selama ini terbatas angka global sehingga sulit dilakukan analisa lebih mendalam. Tuntutan stakeholder dalam hal ini masyarakat adalah pihak pihak pengguna anggaran harus menyajikan laporan secara detail artinya informasi itu makin detail makin menjamin adanya transparansi. Dan diharapkan penyimpangan akan dikurangi secara optimal.

3) Dana alokasi dari tingkat pemerintahan yang lebih tinggi yang diberikan/dikucurkan kepada pemerintahan yang berada dibawahnya harus diberitahukan kepada pemerintahan yang menerimanya sejak APBN/APBD ditetapkan. Pemberitahuan ini dapat diperluas melalui media/ situs pemerintah agar masyarakat ikut terlibat dalam mengawasi penggunaannya. Contoh Dana Bantuan Keuangan (dana kucuran) dari Pemerintah Propinsi/Pemerintah Pusat ke Kabupaten Brebes misalnya haruslah diberitahukan kepada Kabupaten yang bersangkutan sejak APBN/APBD ditetapkan baik melalui mass media, surat kabar, situs resmi pemerintah dan dirinci penggunaannya termasuk satuan harganya. 


\section{KESIMPULAN}

Keterbukaan informasi publik itu diatur dalam UU No. 14 Tahun2008. UU tersebut mewajibkan setiap badan publik untuk membuka akses bagi setiap pemohon informasi publik untuk mendapatkan informasi publik . Namun tidaksemua informasi dapat diakses, seperti jenisinformasi yang dikecualikan. Adapun jenis jenis informasi yakni informasi wajibdisediakan, informasi yang wajib tersedia setiap saat, informasi yang dikecualikan dan informasi yang diperoleh berdasarkanpermintaan. Selanjutnya, prinsip transparansi kebijakanpublik ini memiliki dua aspek yaitu:

1. Komunkasi publik oleh pemerintah

2. Hak masyarakat terhadap akses informasi

Dua aspek tersebut juga memberikanpengaruh terhadap transparansi kebijakanpublik. Keduanya akan sangat sulit dilakukan jika pemerintah tidak menangani dengan baikkinerjanya. Manajemen kinerja yang baikadalah titik awal dari transparansi.Komunikasi publik menuntut usahapemerintah untuk membuka danmendiseminasi informasi maupun aktivitasyang relevan. Transparansi harus seimbang, juga dengan kebutuhan akan kerahasiaanlembaga maupun informasi-informasi yangmempengaruhi hak privasi individu.

Masyarakat menilai jika ada penyimpangan dari hasil kajian yang diperoleh dari data yang bersumber dari pemberitahuan tersebut masyarakat dapat melakukan:

1. Konfirmasi dengan pengguna anggaran/ pemerintah yang bersangkutan untuk memperoleh penjelasan apakah terjadi penyimpangan.

2. Bila terjadi ketidak puasan masyarakat bisa melaporkan kepada pihak yang berwenagn untuk dilakukan audit investigasi. 


\section{DAFTAR PUSTAKA}

Achmadi, dkk, 2002, Good governance dan Penguatan Institusi Daerah, Masyarakat Transparansi Indonesia, Jakarta.

Alamsyah, 1997, Mekanisme Pengawasan APBD di Kabupaten Sleman, Tesis MAP UGM , Jogjakarta.

Arikunto, S. 2006. Prosedur Penelitian Suatu Pendekatan Praktis. Rineka Cipta:Jakarta.

Basri, Yesi Mutia. 2008. Pengaruh pengetahuan Dewan tentang Anggaran. Jurnal Ilmu Administrasi Negara. Volume 8, Nomor 1. Januari 2008. pp. 29-39.

Coryanata, Isma. 2007. Akuntabilitas, Partisipasi Masyarakat, dan Transparansi Kebijakan Publik sebagai Pemoderating Hubungan Pengetahuan Dewan tentangAnggaran dan Pengawasan Keuangan Daerah (APBD). Simposium Nasional Akuntansi X. Makasar.

Dwi Ratmono, Imam Ghozali, 2008. Akuntansi Pemerintah Pusat (APBN) dan Daerah (APBD), Badan Penerbit Universitas Diponegoro, Semarang

Halim. (2004) Otonomi Daerah, Penganggaran Daerah, Dan Korupsi, Seminar Nasional Dalam rangka Dies Natalis ke-44 Fakultas Ekonomi Universitas Diponegoro Semarang.

Mardiasmo. 2002. Otonomi dan ManajemenKeuangan Daerah. Andi. Yogyakarta.

Mardiasmo, 2003, Perwujudan Transparansi dan Akuntabilitas Publik Melalui Akuntansi Sektor Publik Sarana Good Governance, Pidato Pengukuhan Sebagai Guru Besar pada Fakultas Ekonomi Universitas Gajah Mada, Yogyakarta

Mardiasmo, 2004, Akuntansi Sektor Publik, Andi, Yogyakarta

Pramita, Yulinda Devi dan Andriyani, Lilik. 2010. Determinasi Hubungan Pengetahuan Dewan tentang Anggaran dengan Pengawasan Dewan pada Keuangan Daerah (APBD). Simposium Nasional Akuntansi (SNA) XIII Purwokerto.

Peraturan Pemerintah Nomor 58 Tahun 2005 tentang Pengelolaan Keuangan Daerah 
Pramono, Agus H., 2002, Pengawasan Legislative terhadap Ekesekutif dalam Penyelenggaraan Pemerintah Daerah, Tesis S2 Tidak di Publikasikan, Program Pasca Sarjana Ilmu Administrasi Negara, Universitas Brawijaya Malang.

Rahayu, S. 2007. Studi FenomenologisTerhadap Proses Penyusunan AnggaranDaerah Bukti Empiris Dari Satu SatuanKerja Perangkat Daerah Di ProvinsiJambi. Simposium Nasional AkuntansiX, Makasar, 10-12.

Rosalina Pebrica Mayasari, 2012. Pengaruh Kualitas Anggota Dewan Terhadap Pengawasan APBD Dengan Tata Pemerintahan Yang Baik Sebagai Variabel Moderating, Jurnal Ekonomi dan informasi Akuntansi (Jenius), Vol 2, No. 1, Universitas Tridinanti, Palembang.

Simson Werimon, Imam Ghozali, M. Nasir, 2007. Pengaruh Partisipasi Masyarakat Dan Transparansi Kebijakan Publik Terhadap Hubungan Antara Pengetahuan Dewan Tentang Anggaran dengan Pengawasan Keuangan Daerah (APBD), Simposium Nasional Akuntansi X, Universitas Hasanudin, Makassar.

Setyawan, S. 2003. Pengukuran KinerjaAnggaran Keuangan DaerahPemerintah Kota Malang Dilihat dari Perspektif Akuntabilitas. Balance.Agustus.1: 103-114

Sopanah dan Mardiasmo. 2003. Pengaruh Partisipasi Masyarakat dan Transparansi Kebijakan Publik terhadap Hubungan antara Pengetahuan Dewan tentang Anggaran dengan Pengawasan Keuangan Daerah. Simposium Nasional Akuntansi (SNA) VI 16-17 Oktober di Surabaya.

Sri Rahayu,2010. Persepsi Pemerintah Daerah Kota Jambi Terhadap Partisipasi Masyarakat Dan Transparansi Kebijakan Publik Dalam Penyusunan Anggaran Pendapatan Dan Belanja Daerah, Jurnal Penelitian Universitas Jambi, Volume 12, No. 2: 29-34

Triadji, B. 2002. Pengembangan AkuntabilitasKeuangan Daerah. Jurnal Akuntansidan Akuntabilitas Keuangan Daerah.Agustus. Vol 3. No.1: 1-10.

Undang Undang Nomor 17 Tahun 2003 tentang Keuangan Negara

Undang Undang Nomor 33 Tahun 2004 tentang Perimbangan Keuangan Antara Pemerintah Pusat dan Pemerintah Daerah

Undang-Undang No. 14 tahun 2008 tentang Keterbukaan Informasi Publik 
Warsito K,Abdul Rahman, Sri Handayani, 2008. Akuntansi Sektor Publik: Pendekatan Penganggaran Daerah dan Akuntansi Keuangan Daerah, Badan Penerbit Universitas Diponegoro, Semarang

Werimon, Simson, Ghozali, Imam, dan Nazir, Mohamad. 2007. Pengaruh Partisipasi Masyarakat dan Transparansi Kebijakan Publik terhadap Hubungan antara Pengetahuan Dewan tentang Anggaran dan Pengawasan Keuangan Daerah, Artikel, Simposium Nasional Hasil Penelitian Akuntansi 10, Makasar.

Yuwono, S., E.T. Agus dan Hariyandi.2005.Penganggaran Sektor Publik, PedomanPraktis, Penyusunan, Pelaksanaan danPertanggungjawaban APBD. Bayumedia. Malang. 